Analytical Methods

\title{
Direct capture of lactoferrin from cheese whey on supermacroporous column of polyacrylamide cryogel with copper ions
}

\author{
B.M.A. Carvalho ${ }^{\text {a,* }}$, L.M. Carvalho ${ }^{\text {b }}$, W.F. Silva Jr. ${ }^{\text {, }}$, L.A. Minim ${ }^{c}$, A.M. Soares ${ }^{\mathrm{d}}$, G.G.P. Carvalho ${ }^{\mathrm{e}}$, \\ S.L. da Silva ${ }^{a}$ \\ a Department of Chemistry, Biotechnology and Bioprocess Engineering, Federal University of São João Del Rei, Ouro Branco, MG 36420-000, Brazil \\ ${ }^{\mathrm{b}}$ Department of Veterinary, Federal University of Viçosa, Viçosa, MG 36570-000, Brazil \\ ${ }^{\mathrm{c}}$ Department of Food Technology, Federal University of Viçosa, Viçosa, MG 36570-000, Brazil \\ d Oswaldo Cruz Foundation (FIOCRUZ) and Federal University of Rondônia, Porto Velho, RO 76812-245, Brazil \\ ${ }^{\mathrm{e}}$ Department of Animal Science, Federal University of Bahia, Salvador, BA 40110-909, Brazil
}

\section{A R T I C L E I N F O}

\section{Article history:}

Received 16 May 2013

Received in revised form 6 November 2013

Accepted 5 January 2014

Available online 10 January 2014

\section{Keywords:}

IMAC purification

Whey protein

Supermacroporous cryogels

Lactoferrin

\begin{abstract}
A B S T R A C T
Lactoferrin is a protein that is present in cheese whey (a waste product from the dairy industry) and has several biological activities. However, its production from whey must have a high yield and low cost for industrial applications. As such, this study reports the use of polyacrylamide cryogel, loaded with $\mathrm{Cu}^{2+}$ (through the bond with iminodiacetic acid (IDA)), as an adsorbent for the chromatographic process to capture lactoferrin whey. Ultrafiltered cheese whey was passed through the cryogel-IDA-Cu ${ }^{2+}$ system. The eluates were subjected to analysis of total protein, SDS-PAGE and size exclusion chromatography. The results showed an axial dispersion coefficients, at different superficial velocities of liquid, in a range of $10^{-6}-10^{-5} \mathrm{~m}^{2} / \mathrm{s}$. The cryogel demonstrated good hydraulic permeability $\left(4.7086 \times 10^{-13} \mathrm{~m}^{2}\right)$ and a porosity of approximately $78.2 \%$. The IDA-Cu ${ }^{2+}$ cryogel system was also able to capture lactoferrin in high purity.
\end{abstract}

(c) 2014 Elsevier Ltd. All rights reserved.

\section{Introduction}

The lactoferrin obtained from whey is a glycoprotein with molar mass of about $80 \mathrm{kDa}$ and has an iron atom bound to the molecule. Lactoferrin is considered an important defense molecule and has a variety of other physiological functions and biological properties, such as antiviral, antibacterial, antioxidant and immunomodulatory activities (UniProt: B9VPZ5). During the last decade, it has become clear that oral administration of lactoferrin exerts various benefits on human and animal health, including anticancer and anti-inflammatory effects (Wakabayashi, Yamauchi, \& Takase, 2006).

All these beneficial features of lactoferrin lead indicate that it has a high potential for applications as a feed additive. Some studies have attempted to purify lactoferrin by cation exchange chromatography, by heparin Sepharose affinity chromatography, by affinity chromatography using peptides (Noppe et al., 2006) and heparin affinity polyglycidyl-methacrylate (Chen, Guo, \& Guan \& Liu, 2007).

Continuous phase chromatographic columns, which are known as cryogels (polymeric gels formed in moderately frozen conditions), have become a very useful technology in the

\footnotetext{
* Corresponding author. Tel.: +55 0213137413962.

E-mail address: brunamara.carvalho@gmail.com (B.M.A. Carvalho).
}

bioseparation field (Carvalho et al., 2014). Cryogels were introduced as new separation matrixes; due to their interconnected large-dimension pore structure, the flow through the pores is purely convective and the resistance to mass transfer is low (Lozinsky, Plieva, Galaev, \& Mattiasson, 2001). The cryogels that are currently in use are therefore excellent as a chromatographic material, allowing the direct capture of proteins and other biomolecules from crude extracts or even from unprocessed fermentation media (Arvidsson et al., 2002).

Immobilized metal ion affinity chromatography (IMAC), introduced by Porath and collaborators in 1975, is effective for isolating proteins from non-clarified mixtures (Carvalho et al., 2013). IMAC employs chelated metal ions, such as $\mathrm{Cu}^{2+}, \mathrm{Ni}^{2+}, \mathrm{Zn}^{2+}$, among others, as a coordination agent for protein links. Supermacroporous cryogels that have continuous columns of poly(acrylamide), modified with iminodiacetic acid residues, have been used for immobilized metal ion affinity chromatography to directly capture enzymes from cell homogenates, such as lactate dehydrogenase (Arvidsson et al., 2002), urokinase (Kumar, Bansa, Arvidsson, Roychoudhury, \& Mattiasson, 2006; Kumar, Bansal, Nandakumar, Galaev, \& Roychoudhury, 2006), trypsin, $\beta$-galactosidase, lactoferrin (Noppe et al., 2007), monoclonal antibodies, bacteriocins (Deraz, Plieva, Galaev, Karlsson, \& Mattiasson, 2007) and cytochrome c (Çimen \& Denizli, 2012). 
The use of cryogel matrices for the IMAC technique opens up new perspectives for the use of chromatographic processes in protein purification. As such, the present study aimed to purify lactoferrin from cheese whey using supermacroporous cryogels with continuous columns of poly(acrylamide) and immobilized $\mathrm{Cu}^{2+}$.

\section{Materials and methods}

\subsection{Materials}

Acrylamide (AAm, 99.9\% electrophoretic grade), N,N'-methylenebisacrylamide (99\% MBAAm), ammonium persulfate (APS, $98 \%$ ), $\mathrm{CuSO}_{4} \cdot 4 \mathrm{H}_{2} \mathrm{O}$ (98\%), iminodiacetic acid (IDA), 4-(2-hydroxyethyl)-1-piperazineethanesulfonic acid (HEPES), N,N, $\mathrm{N}^{\prime}, \mathrm{N}^{\prime}$-tetramethylethylenediamine (99\% TEMED) and allyl glycidyl ether (AGE, 99\%) were purchased from Sigma-Aldrich (Steinheim, Germany). Imidazole was purchased from Merck (Germany). The ultrafiltered cheese whey ( $12 \%$ total solids) was obtained from the production of fresh cheese and was processed in an ultrafiltration membrane system (10 kDa WGM). Ultrapure water was used for all experiments (Milli-Q system, Millipore Inc., USA); all chemical reagents were of high analytical degree and protein standards were from Sigma Aldrich.

\subsection{Methods}

\subsubsection{Production of continuous column supermacroporous cryogels}

The matrices were produced with a completely randomized design, with five variants and three replications. The synthesis of the matrices (variants 1, 2, 3 and 4) was performed according to Arvidsson, Plieva, Lozinsky, Galaev, and Mattiasson (2003), with some adaptations. Acrylamide and $\mathrm{N}, \mathrm{N}^{\prime}$-methylenebisacrylamide monomers were added in the following proportions; treatment 1: AAm/MBAAm $(\mathrm{mol} / \mathrm{mol})=30: 1$, treatment 2: AAm/MBAAm $(\mathrm{mol} / \mathrm{mol})=20: 1$, treatment 3: AAm $/$ MBAAm $(\mathrm{mol} / \mathrm{mol})=10: 1$, treatment 4: AAm/MBAAm $(\mathrm{mol} / \mathrm{mol})=5: 1$. The monomers were dissolved in $30 \mathrm{~mL}$ of Milli-Q ultrapure deionized water and immersed in an ultrasound bath (Quimis Q335D) to remove dissolved air microbubbles in the solution. The gels were produced by free radical polymerization, initiated by TEMED and APS. After the addition of TEMED $(15 \mu \mathrm{L})$, the solution was cooled in an icebath (about $5^{\circ} \mathrm{C}$ ) for $2-3 \mathrm{~min}$. Subsequently, APS (7.5 mg) was added and the mixture was stirred for $1 \mathrm{~min} .5 \mathrm{~mL}$ of this mixture were added in $5 \mathrm{~mL}$ plastic syringes. The syringes were maintained frozen at $-11^{\circ} \mathrm{C}$ for $24 \mathrm{~h}$ in an ultrathermostatic bath (Quimis Q214M). After this step, the columns were thawed at room temperature and then washed with $200 \mathrm{~mL}$ ultrapure Milli-Q water at a rate of $1 \mathrm{~mL} \mathrm{~min}{ }^{-1}$. The samples were dried at $60{ }^{\circ} \mathrm{C}$ until a constant weight.

The formation of the cryogel matrices for treatment 5 was carried out according to Kumar, Bansa, Arvidsson, et al. (2006). Monomers (4.74 g of acrylamide, $1.27 \mathrm{~g}$ of MBAAm and $1.0 \mathrm{~mL}$ of AGE) were dissolved in deionized Milli-Q water to a final concentration of $6 \%$. The mixture was degassed under vacuum (water pump aspirator) for about $5 \mathrm{~min}$ to eliminate soluble oxygen. The gels were produced by free radical polymerization, which was initiated by the addition of TEMED $(95 \mu \mathrm{L})$ and APS $(110 \mathrm{mg})$ under low temperature. The mixture was transferred to plastic syringes $(5 \mathrm{~mL})$, which were frozen at $-12{ }^{\circ} \mathrm{C}$ for $16 \mathrm{~h}$. The cryogel matrices were washed with $200 \mathrm{~mL}$ ultrapure Milli-Q water at a flow rate of $1 \mathrm{~mL} \mathrm{~min}{ }^{-1}$. Samples were dried at $60^{\circ} \mathrm{C}$ until constant weight.

\subsubsection{Characterization of cryogel matrices}

2.2.2.1. Swelling capacity. The swelling capacity $\left(S_{\mathrm{w} / \mathrm{w}}\right)$ of the cryogel was determined, according to Arvidsson (2003)), by immersion of the matrices in containers containing water for $2 \mathrm{~h}$. The containers were stirred manually and slowly every $15 \mathrm{~min}$. The excess water was then removed from the matrices and their wet weight $\left(m_{\mathrm{w}}\right)$ was measured. The matrices were dried at $60^{\circ} \mathrm{C}$ until constant weight, and the masses of the dried samples $\left(m_{\mathrm{d}}\right)$ were determined to calculate the swelling capacity using Eq. (1).

$S_{\mathrm{w} / \mathrm{w}}=\left(m_{\mathrm{w}}-m_{\mathrm{d}}\right) / m_{\mathrm{d}}$

where $S_{\mathrm{w} / \mathrm{w}}$ is the swelling capacity $\left(\mathrm{g} \mathrm{H}_{2} \mathrm{O} / \mathrm{g}\right.$ dry gel), $m_{\mathrm{w}}$ and $m_{\mathrm{d}}$ are the weights $(\mathrm{g})$ of the wet and dry samples, respectively.

2.2.2.2. Porosity. The porosity of the cryogel monolith was estimated by measuring the free water content and the volume of the monolith (Yao et al., 2006). A sample of about $3 \mathrm{~cm}$ in length was cut from the middle of the cryogel monolith and saturated with deionized water. The sample was then immersed in a beaker containing deionized water with a previously known volume $\left(V_{1}\right)$; following immersion, the new volume $\left(V_{2}\right)$ was determined. The sample volume $\left(V_{0}\right)$ was calculated by subtracting both volumes, i.e., $V_{0}=V_{2}-V_{1}$. The mass of the sample that was saturated with water, $m_{\mathrm{w}}$, was weighed. The sample was squeezed to remove the free water within the large pores using the same procedure as that reported by Yao et al. (2006), and the mass of the sample without free water $\left(m_{s}\right)$ was recorded. The porosity was then calculated by Eq. (2):

$\varphi=\frac{m_{\mathrm{w}}-m_{\mathrm{s}}}{\rho_{\mathrm{w}} V_{0}}$

where $\rho_{\mathrm{w}}$ is the deionized water density. Then sample was dried in an oven at $60^{\circ} \mathrm{C}$ until constant weight. The dry mass $\left(m_{\mathrm{d}}\right)$ was then determined and was used to calculate the total water fraction using the expression below:

$m_{\mathrm{w}}-m_{\mathrm{d}} / p_{\mathrm{w}} V_{0}$

2.2.2.3. Resistance to flow. The resistance to flow provided by the column was evaluated by the ratio of the hydrostatic pressure drop through the column (using a high performance chromatographic system (Shimadzu, Japan) to perform the measurements) versus the flow rate of the mobile phase. The hydraulic permeability, $k_{\mathrm{w}}$, was calculated using Darcy's law, according to the following equation (Yao et al., 2006):

$k_{\mathrm{w}}=\frac{Q_{\mathrm{w}} \mu_{\mathrm{w}} L}{\Delta p_{\mathrm{w}} A}$

where $Q_{w}$ is the water flow through the column, $\mu_{\mathrm{w}}$ the water viscosity $r, L$ the column length, $A$ the cross-section area and $\Delta p_{\mathrm{w}}$ is the pressure drop, respectively.

Deionized water was passed through the column at different flow rates $\left(0.1,5 \mathrm{~mL} \mathrm{~min}^{-1}\right)$ and the $\Delta p$ for each flow was measured and used to calculate the hydraulic permeability.

2.2.2.4. Axial dispersion. Deionized water was pumped through the column in a high performance chromatographic system (Shimadzu, Japan) at a constant rate. A pulse of non-reactive tracer $(0.15 \mathrm{~mL}$ of acetone at $3 \% \mathrm{v} / \mathrm{v})$ was injected into the column and the corresponding response was measured in the column outlet by a detector at a UV absorbance of $280 \mathrm{~nm}$. The data recorded for different flow values were used to calculate the residence time distribution (DTR). The axial dispersion coefficient was determined by the variance and the mean residence time curve, corresponding to DTR (Yao et al., 2006), according to the equation below:

$\frac{\sigma_{t}^{2}}{\bar{t}^{2}}=2\left(\frac{D_{\mathrm{ax}}}{v L}\right)-2\left(\frac{D_{\mathrm{ax}}}{v L}\right)^{2}\left[1-\exp \left(-\frac{v L}{D_{\mathrm{ax}}}\right)\right]$ 
Where $\sigma_{t}^{2}$ and $\bar{t}$ are the variance and the mean residence time curve (RTD), $D_{\mathrm{ax}}$ is the axial dispersion coefficient, $L$ is the column length and $v$ is the interstitial fluid speed through the column $\left(v=U_{L} / \varphi\right.$, where $\varphi$ is the bed porosity and $U_{L}$ is the superficial velocity). The theoretical plate number of the column $(N)$ was calculated from the DTR results, and the values of the height equivalent for a theoretical plate (HETP) were obtained from the calculated column length (Yao et al., 2006). The Bodenstein number $\left(\mathrm{Bo}=v L / D_{\mathrm{ax}}\right)$, which is the ratio between the convective transport to the dispersive transport (Bruce \& Chase, 2001), was calculated and used to describe the efficiency and the dispersion degree in the cryogel column.

2.2.2.5. Scanning electron microscopy (SEM). The microscopy surface of coupons $(20 \times 50 \mathrm{~mm})$ from each treatment was observed and photographed with a LEO 1430 VP scanning electronic microscope (SEM; Carl Zeiss, Cambridge, England) at the Center for Microscopy and Microanalysis of Federal University of Viçosa (Poster, Howard, Johnson, \& McMichael, 1980).

\subsubsection{Preparation of IDA-Cu ${ }^{2+}$ cryogel system}

The Preparation of IDA-Cu ${ }^{2+}$ cryogel system was carried out, according to Kumar, Bansal, Nandakumar, Galaev, Roychoudhury, 2006. $\mathrm{Na}_{2} \mathrm{CO}_{3}$ solution ( $50 \mathrm{~mL}, 0.5 \mathrm{~mol} \mathrm{~L}^{-1}$ ) was pumped through the cryogel at a rate of $1 \mathrm{~mL} \mathrm{~min}{ }^{-1}$, followed by $1 \mathrm{~mol} \mathrm{~L}^{-1} \mathrm{Na}_{2} \mathrm{CO}_{3}$ solution $(50 \mathrm{~mL})$ at the same rate. The IDA solution $\left(0.5 \mathrm{~mol} \mathrm{~L}^{-1}\right.$ in $1.0 \mathrm{~mol} \mathrm{~L}^{-1} \mathrm{Na}_{2} \mathrm{CO}_{3}, \mathrm{pH} 10.0$ ) was applied to the column at a flow rate of $1 \mathrm{~mL} \mathrm{~min}^{-1}$ in reflux for $24 \mathrm{~h}$ at room temperature. After this, the modified gel was washed with $0.5 \mathrm{~mol} \mathrm{~L}^{-1} \mathrm{Na}_{2} \mathrm{CO}_{3}$ solution $(100 \mathrm{~mL})$ and then with deionized water until $\mathrm{pH}$ 8.0. A solution $0.1 \mathrm{~mol} \mathrm{~L}^{-1}$ copper sulphate $(30 \mathrm{~mL}$ ) was pumped through the column in reflux at a rate of $1 \mathrm{~mL} \mathrm{~min}^{-1}$ for $2 \mathrm{~h}$. Finally, the cryogel was washed with deionized water to remove unbound metal and then washed with imidazole buffer (15 mM HEPES and $0.2 \mathrm{~mol} \mathrm{~L}^{-1} \mathrm{NaCl}, \mathrm{pH} 7.0$ ) to remove weakly-bound metals.

\subsubsection{Capture of lactoferrin from cheese whey}

The capture of lactoferrin was conducted, according to Cheeks et al. (2008), with some modifications. A volume of ultrafiltered cheese whey $(20 \mathrm{~mL})$ was inserted into the chromatographic column (HR5/5 Pharmacia Biotech) containing the cryogel immobilized with $\mathrm{Cu}^{2+}$ and previously equilibrated with 6 column volumes (CV) of equilibrium buffer (20 mM HEPES in $200 \mathrm{mM}$ $\mathrm{NaCl}, \mathrm{pH}$ 6.8) at a flow rate of $1 \mathrm{~mL} \mathrm{~min}^{-1}$. After passing ultrafiltered whey through the column, it was washed with equilibrium buffer $(8 \mathrm{CV})$. The elution of the adsorbed protein was performed by applying $4 \mathrm{CV}$ of imidazole buffer $(200 \mathrm{mM}, \mathrm{pH} 7.4)$ at a $1 \mathrm{~mL} \mathrm{~min}^{-1}$ flow rate. The protein fractions collected off the column during the elution step were lyophilized and submitted to the analytical determinations of total protein concentration, gel electrophoresis and molecular exclusion chromatography.

\subsubsection{Quantification of total protein}

The quantification of proteins in the chromatography fractions was determined by Bradford (1976) using bovine serum albumin (BSA; Sigma, USA) as the reference protein.

\subsubsection{SDS-PAGE}

The protein fractions obtained from the adsorption steps (washing and elution) were compared with standards of whey proteins by SDS-PAGE electrophoresis on Sigma equipment (model Z35, $280-2$ ), using the polyacrylamide gel at a concentration of $7.5 \%$. All samples were treated with SDS-containing buffers and $\beta$ mercaptoethanol. The samples were heated at $100{ }^{\circ} \mathrm{C}$ for $10 \mathrm{~min}$. Aliquots of $10-15 \mu \mathrm{L}$ of each sample were applied to the gel, which was subjected to a voltage of $180 \mathrm{~V}$ in a horizontal vat and colored with cromassie blue.

\subsubsection{Gel filtration chromatography}

Fractionation of proteins by gel filtration chromatography (sizeexclusion chromatography) was conducted in an Agilent ZORBAX column (Bio Series GF-450), which was initially equilibrated with $4 \mathrm{CV}$ of $0.2 \mathrm{~mol} \mathrm{~L}^{-1}$ phosphate buffer, $0.8 \mathrm{~mol} \mathrm{~L}^{-1} \mathrm{Na}_{2} \mathrm{HPO}_{4}$ and $5 \% \mathrm{NaCl}, \mathrm{pH} 8.5$, at a flow rate of $1 \mathrm{~mL} \mathrm{~min}^{-1}$. The sample from the IMAC elution $(50 \mu \mathrm{L})$ was injected into the column buffer at a flow rate of $1 \mathrm{~mL} \mathrm{~min}{ }^{-1}$. The eluate was monitored by UV detection at $280 \mathrm{~nm}$. Proteins were identified according to a previously prepared calibration curve, applying the pattern of major proteins found in cheese whey.

\subsubsection{Lactoperoxidase activity}

To ensure the purity of retained lactoferrin, lactoperoxidase activity was determined using the ABTS [2,2-azinobis(ethylbenzothiazoline-6-sulfonic acid) diammonium salt] method. The sample of ultrafiltered cheese whey was passed through the chromatographic cryogel column with immobilized $\mathrm{Cu}^{2+}$, and lactoperoxidase activity measured in the protein fractions collected from the column during the elution step (Putter \& Becker, 1983).

\section{Results and discussion}

\subsection{Preparation and characterization of cryogels with different concentrations of monomers and the presence of $A G E$}

The continuous supermacroporous cryogel adsorbents are spongy and elastic. The adsorbent cylinder may be removed and replaced in a single chromatographic column by simply removing the liquid excess from the cylinder and placing slight pressure between the inner wall of the syringe and the gel. Approximately $4 \mathrm{~mL}$ of water may be extracted $5 \mathrm{~mL}$ of gel, corresponding to the estimated flow through the pore volume. The adsorbent can be dried and hydrated without loss of its properties.

Scanning electron microscopy of the cryogels (Fig. 1) clearly demonstrates the difference between the different variants applied during the preparation of matrices and the presence of large pores (10-100 $\mu \mathrm{m})$ with interconnected smooth and thick walls. When the AAm/MBAAm ratio was changed in variants 1-4 (Fig. 1), alterations in pore structure were observed. As the ratio decreases, the pores became thinner. Importantly, the matrix structure was seen to remain intact even after the drying process. The cryogel formed with epoxy groups (Fig. 1e) demonstrated visible differences in its external and internal structure, when compared to other variants. The polarity of these groups creates interaction forces between the epoxy molecule and the surface adjacent to it. The monoliths obtained by the treatment with AGE were stronger and easier to handle due to a firmer structure that resulted from the polarity of the hydroxyl groups and aliphatic ethers, which participate in the chain matrix.

The swelling capacities of variants $1,2,3,4$ and 5 were 3.95 , 3.62, 3.32, 2.32 and $3.60 \mathrm{~g} \mathrm{H}_{2} \mathrm{O} / \mathrm{g}$ dry gel, respectively. The ability to swell decreased with decreasing AGE and a decreasing AAm/ MBAAm ratio. While AAm is responsible for the linearity of the chains, the crosslinked MBAAm provides the polymerization stage. Thus, the closer the ratio of AAm/MBAAm is to 1, the more compact the structure formed is, leading to a lower swelling capacity. The matrices containing epoxy groups presented intermediate swelling capacity values, when compared with other variants, probably due to the more rigid structures observed. The evaluation of swelling capacity is a measurement of cryogel matrix expansion; thus, for further analyses, cryogel matrices with lower swelling capacity values were chosen. Matrices with larger swelling values are more malleable (after swelling) and can, therefore, probably bear less pressure (Fig. 2). 


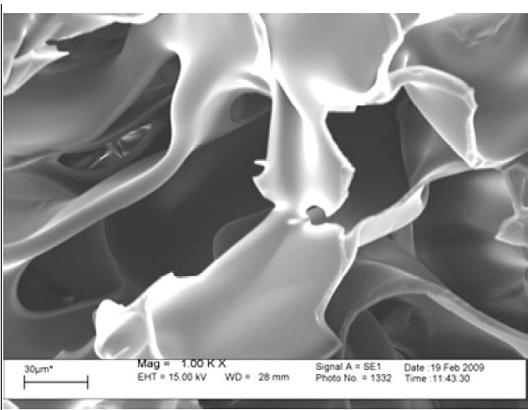

(a)

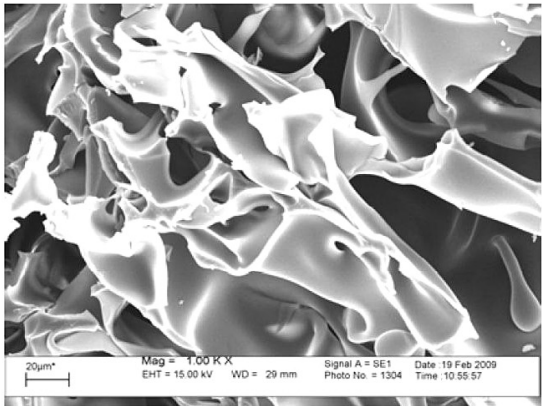

(b)

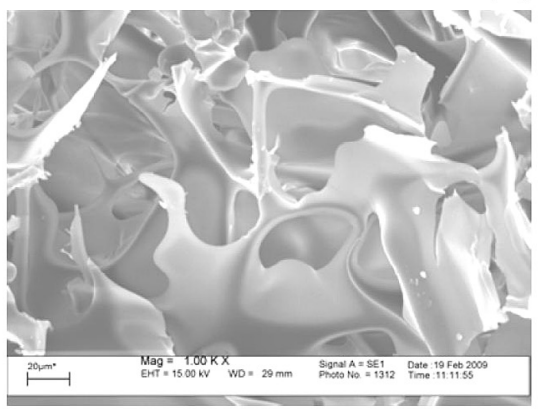

(c)

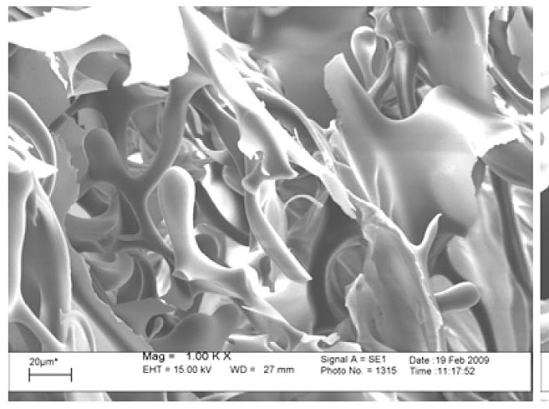

(d)

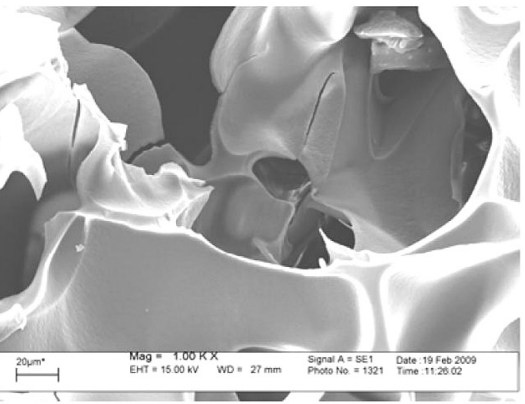

(e)

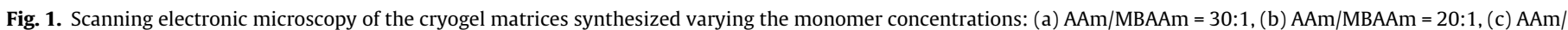
MBAAm = 10:1, (d) AAm/MBAAm = 5:1 and (e) AAm/MBAAm = 30:1 + AGE.

The cryogel monolith porosities, $\varphi$, for treatments 1, 2, 3, 4 and 5 were $88.3 \%, 86.9 \%, 75.4 \%, 71.2 \%$ and $78.2 \%$, respectively. These results indicate that cryogels containing epoxy groups, provided by the glycidyl allyl ether (AGE), also have intermediate porosity values, when compared with other variants. Data support those obtained by other authors (Arvidsson, Plieva, Lozinsky, Galaev, \&

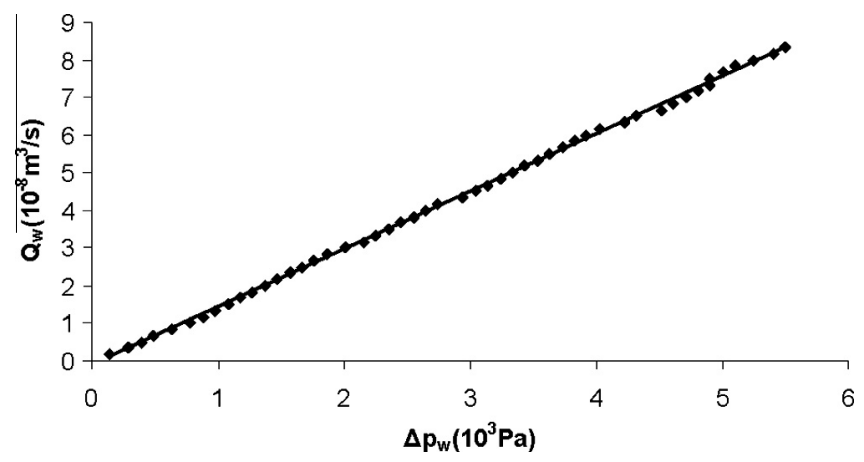

Fig. 2. Experimental and theoretical flow rates as a function of pressure drop in the column cryogel containing epoxy groups $\left(\mu_{\mathrm{w}}=1.0030 \times 10^{-3} \mathrm{~Pa}\right.$.s, $\left.L=6.0 \times 10^{-2} \mathrm{~m}\right) .(\checkmark)$ experimental data and (-) theoretical data.
Mattiasson, (2003); Dainiak, Kumara, Plieva, Galaev, \& Mattiasson, 2004; Kumar, Plieva, Galaev, \& Mattiasson, 2003; Persson et al., 2004; Plieva, Andersson, Galaev, \& Mattiasson, 2004; Plieva et al., 2004). The total water content in the cryogel monolith chosen for the lactoferrin purification, treated with AGE, was $92.8 \%(\mathrm{v} / \mathrm{v})$. Thus, approximately $14.6 \%$ of the total water was trapped by the matrices and the small pores, where almost no fluid stream passes.

The residence time distributions (DTRs) were measured in the cryogels and presented liquid superficial velocities of $0.5,1,2,3$, $4,6,8,10,12$ and $15 \mathrm{~cm} \mathrm{~min}^{-1}$, respectively. Fig. 3 shows the DTRs of some liquid superficial velocities. The DTR curves demonstrated a wider peak width for lower liquid flow rates. The axial dispersion coefficient at different superficial velocities of liquid was calculated according to Eq. (4), and the results are shown in Fig. 4. It may be observed that the axial dispersion coefficient, under these conditions, ranged from $10^{-6}$ to $10^{-5} \mathrm{~m}^{2} \mathrm{~s}^{-1}$.

The values of height equivalent to a theoretical plate (HETP) of RTDs ranged from 0.61 to $0.77 \mathrm{~mm}$, which was similar to a report by Yao et al. (2006), who related HETPs of $0.56-0.75 \mathrm{~mm}$. These authors characterized supermacroporous cryogel continuous matrices containing magnetic nanoparticles; the axial dispersion coefficient values obtained were lower than those obtained in an expanded bed or fluidized bed under similar flow conditions 


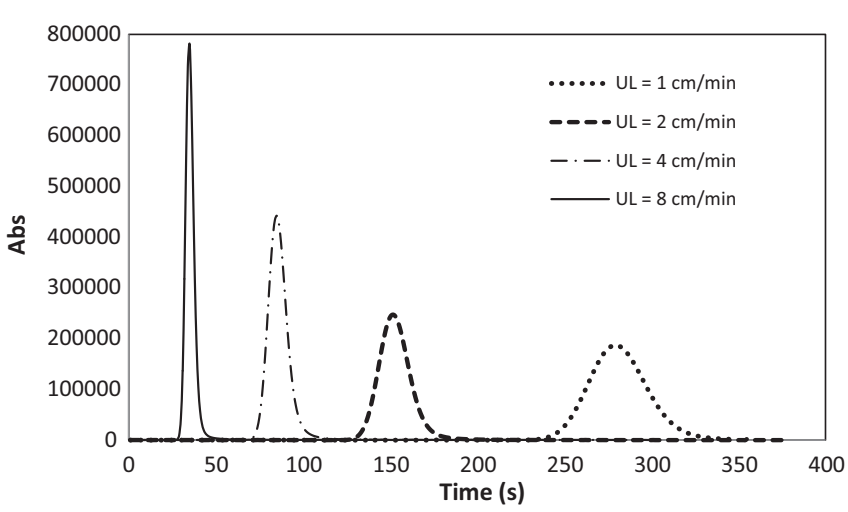

Fig. 3. Distribution curves of the residence time in some liquid superficial velocities in the matrix of IDA-Cu ${ }^{2+}$-cryogel.

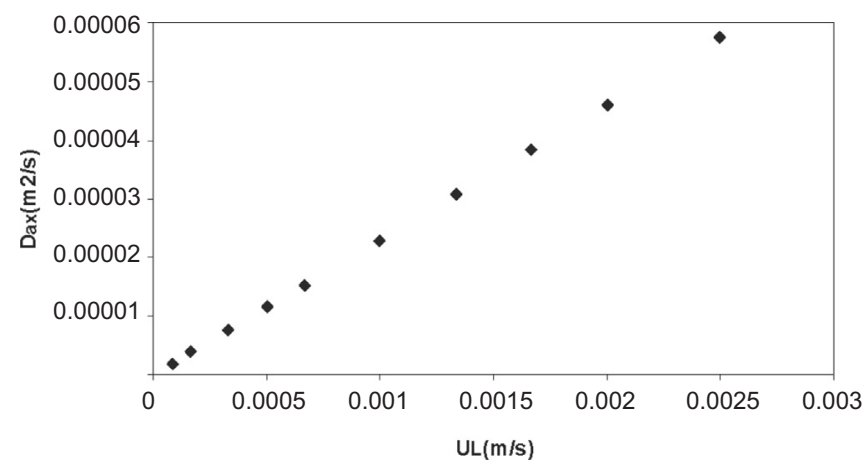

Fig. 4. Axial dispersion coefficients at different superficial velocities of flow in the cryogel column.

(Yun, Lin, \& Yao, 2004; Yun, Yao, \& Lin, 2005). One explanation for this result is that, for these bed types, the mobile phase remains in the suspended particles of the adsorbent, increasing of the bed porosity, thereby allowing the fluid pass through the column without increasing the flow resistance. Therefore, the dispersion of the liquid column within the cryogel is weak, for these conditions of measurement. Fig. 6 demonstrates that the axial dispersion coefficient increases with the increasing liquid speed.

The experimental results for the flow resistance are shown in Fig. 4. The water permeability $\left(k_{\mathrm{w}}\right)$ obtained in the monolithic cryogel bed was $4.7086 \times 10^{-13} \mathrm{~m}^{2}$. This value was lower than that reported by other authors for organic polymeric monolith (Yao et al., 2006).

\subsection{Purification of lactoferrin from whey using the IDA-Cu ${ }^{2+}$ cryogel complex}

Table 1 shows the minimal retention of the proteins present in the whey and eluates ( $\alpha$-lactalbumin, $\beta$-lactoglobulin, bovine serum albumin (BSA), glycomacropeptide (GMP), lactoperoxidase and Lactoferrin). Different retention times for each standard protein can be observed due to their different molecular masses. Similar retention times were seen for lactoferrin (standard) and the eluates from the chromatographic purification process, which implies the presence of lactoferrin in the eluates collected.

Copper ion was used in this study to interact with the protein. This metal was selected based on studies showing that the retention strengths of IMAC for proteins with accessible histidines on their surfaces (as in the case of lactoferrin) increase in the presence of metal ions (in the following order): $\mathrm{Cu}^{2+}>\mathrm{Ni}^{2+}>\mathrm{Zn}^{2+}=$ $\mathrm{Co}^{2+}$. Similar results were found in other studies such as those by

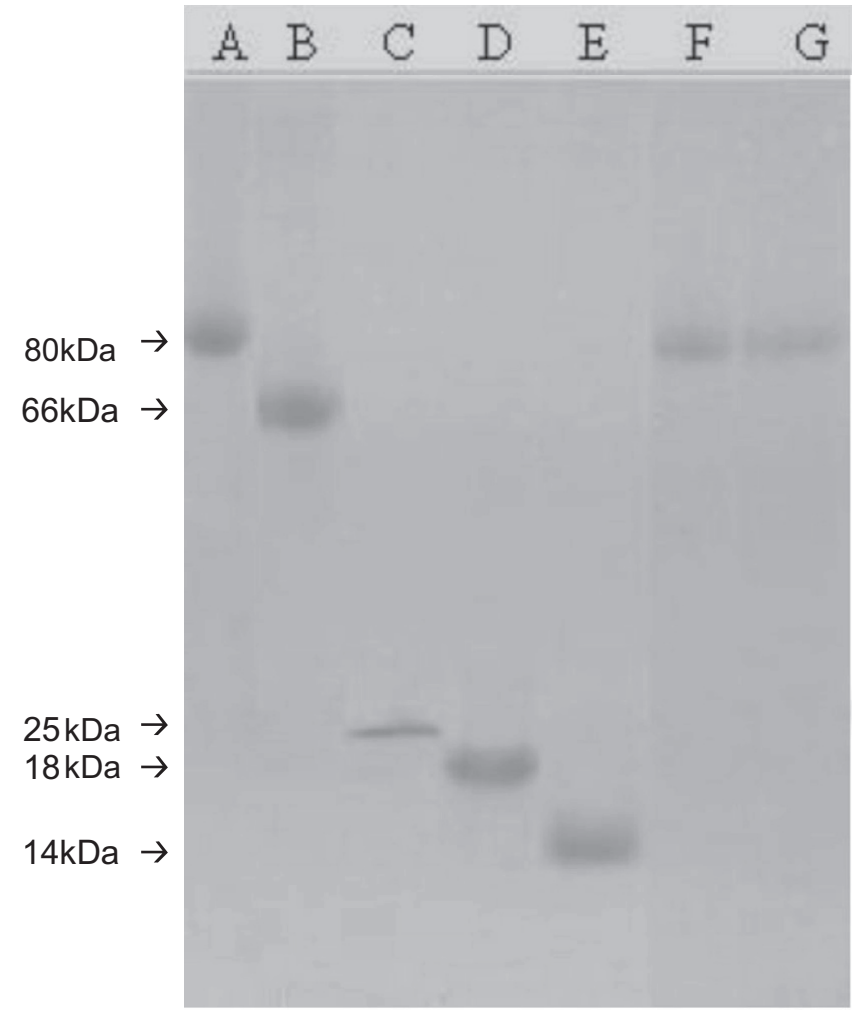

Fig. 5. SDS-PAGE $7.5 \%$ (180 V running): (A) lactoferrin $\left(10 \mathrm{mg} \mathrm{mL}^{-1}\right)$, (B) BSA $\left(5 \mathrm{mg} \mathrm{mL}^{-1}\right)$, (C) GMP $\left(10 \mathrm{mg} \mathrm{mL}^{-1}\right)$, (D) $\beta$-lactoglobulin $\left(10 \mathrm{mg} \mathrm{mL}^{-1}\right)$, (E) $\alpha$ lactalbumin (10 $\left.\mathrm{mg} \mathrm{mL}^{-1}\right)$, (F) eluted I $(\mathrm{G})$ eluted II.

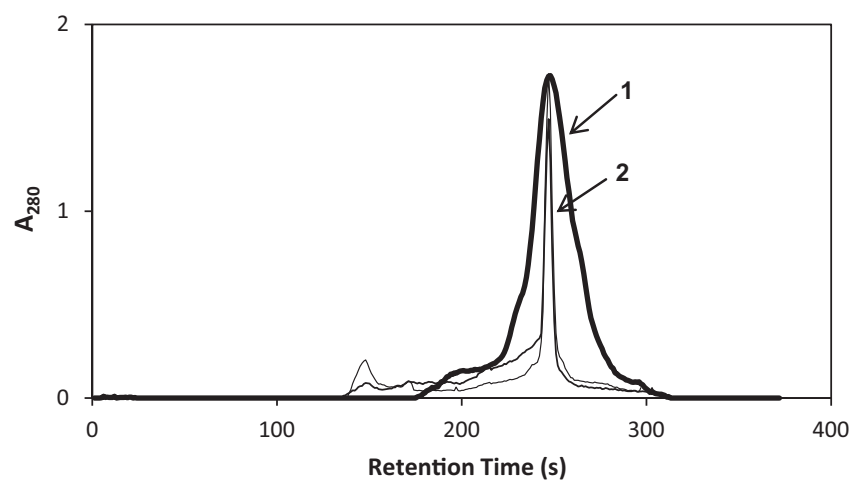

Fig. 6. Chromatographic profile of lactoferrin purified in IDA-Cu${ }^{2+}$-cryogel system. Peak 1 = Lactoferrin pure; Peak 2 = eluates (I and II). All procedures were done in Agilent ZORBAX column (Bio Series GF-450) equilibrated with buffer $0.2 \mathrm{M}$ $\mathrm{Na}_{2} \mathrm{HPO}_{4}$ in $0.8 \mathrm{M} \mathrm{NaCl}$ and $5 \%$ methanol, $\mathrm{pH} 8.5$ at a flow rate of $1 \mathrm{~mL} / \mathrm{min}$.

Plieva, Andersson, et al. (2004) who used IDA-Cu ${ }^{2+}$ cryogel for the purification of bioparticles and obtained excellent results. The HEPES buffer system was employed, as this buffer provides better selectivity for the IDA- $\mathrm{Cu}^{2+}$ cryogel complex (Wang et al., 2008).

Lactoperoxidase activity was $27 \mathrm{U} / \mathrm{mL}$ in $21 \mathrm{~mL}$ of whey after passing through the IDA-Cu${ }^{2+}$ cryogel and $0.0031 \mathrm{U} / \mathrm{mL}$ in $2 \mathrm{~mL}$ of elute. Results indicate that the lactoperoxidase may elute out with the whey and is not retained in the IDA-Cu${ }^{2+}$ cryogel system. The conditions used for the equilibration and elution buffer did not favor the deprotonation or protonation of the histidines of lactoperoxidase, and therefore compromised the retention of the enzyme in the IDA- $\mathrm{Cu}^{2+}$ cryogel system. To determine the protein 
Table 1

Retention times of protein standards and eluted (obtained from the purification of lactoferrin in IDA-Cu ${ }^{2+}$-cryogel using ultrafiltered cheese whey).

\begin{tabular}{ll} 
Sample & ${\text { Retention } \text { times }^{\mathrm{a}}(\mathrm{s})}^{\mathrm{L}}$ \\
\hline Lactoperoxidase & 216 \\
Lactoferrin & 250 \\
BSA & 283 \\
GMP & 315 \\
$\alpha$-Lactalbumin & 327 \\
$\beta$-Lactoglobulin & 339 \\
Eluted I & 248 \\
Eluted II & 248
\end{tabular}

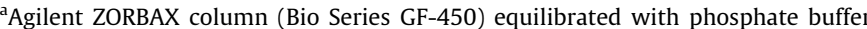
$0.2 \mathrm{M} \mathrm{Na}_{2} \mathrm{HPO}_{4}$ in $0.8 \mathrm{M} \mathrm{NaCl}$ and $5 \%$ methanol, pH $8.5 \mathrm{~A}$ a flow rate of $1 \mathrm{~mL} / \mathrm{min}$.

purity, SDS-PAGE analysis of the eluted fractions from the IDA- $\mathrm{Cu}^{2+}$-cryogel was used and showed that lactoferrin was adsorbed by binding with copper (Figs. 5 and 6). Dense bands of approximately $80 \mathrm{kDa}$ were found in the eluates $(\mathrm{F}, \mathrm{G})$. As no other band was found in the eluates, the purity of the lactoferrin separated from whey using the IDA- $\mathrm{Cu}^{2+}$-cryogel system was confirmed. The chromatograms of lactoferrin and eluates are presented in Fig. 6. The similarity between the peaks reinforces the purity of the purified protein in the IDA- $\mathrm{Cu}^{2+}$-cryogel system.

Similar results were found by Billakanti and Fee (2009), who studied the applicability of cryogels for the extraction of proteins from bovine milk by cation exchange interaction. According to Billakanti (2009), cryogel monoliths have approximately 25 times less binding dynamic capacity when they are compared, for example, with a commercial material such as SP Sepharose. In the preparation of cryogel, the obtained pores occupy about $80 \%$ of the total volume of the column. Thus, the surface area available to bind proteins is lower compared to other absorption systems. High flow rates and large volumes of whey were achieved in cryogels, but the main challenge in developing these materials is to improve their binding capacity. Other factors such as low material cost and the wide variety of functional groups available for binding to cryogels suggest that they may represent an alternative for the secondary extraction of proteins from milk and serum. In our study, the binding capacity of the lactoferrin to the cryogel column was about $0.3 \mathrm{mg} / \mathrm{mL}$ of resin. This value is close to those values recorded by other researchers. Billakanti and Fee (2009), studied the extraction of minor proteins from milk by cation exchange in cryogel monoliths, and found adsorption capacity values, at equilibrium, of approximately $3 \mathrm{mg}$ of lactoferrin/mL of resin. Wang et al. (2008), evaluated the binding capacities of BSA at different solution $\mathrm{pHs}$ for the $\mathrm{Zn}^{2+}$-IDA cryogel and $\mathrm{Ni}^{2+}$-IDA cryogel, and related values of around $4.4 \mathrm{mg} / \mathrm{mL}$ of resin.

Immobilized metal ion affinity chromatography (IMAC; IDA$\mathrm{Cu}^{2+}$-cryogel) has been used for the separation of different types of microbial cells, since these cells present available histidine residues (Dainiak, Plieva, Yu, Galaev, \& Mattiasson, 2005). Proteins that naturally contain accessible histidine residues (recombinant or not) and have commercial importance in therapy and diagnosis include human serum proteins (Porath \& Olin, 1983), immunoglobulin (Ribeiro, Vijayalakshmi, Todorova-Balvay, \& Bueno, 2008) and human growth hormone, which can be purified by IMAC using the immobilized transition metals, $\mathrm{Cu}^{2+}, \mathrm{Ni}^{2+}, \mathrm{Zn}^{2+}, \mathrm{Fe}^{3+}$ and $\mathrm{Co}^{2+}$. Other metal ions, such as $\mathrm{Al}^{3+}, \mathrm{Ca}^{2+}$ and $\mathrm{Yb}^{3+}$ have been used for the purification of transferrin, albumin, $\alpha 2$-macroglobulin and $\gamma$-globulins, achieving high selectivity, and representing an attractive alternative for the selective fractionation of human serum proteins (Zachariou \& Hearn, 2000).

The affinity of proteins for immobilized metal ions may also be exploited for other techniques, such as cell separation, protein and nucleic acid (Zachariou \& Hearn, 2000) partition by aqueous two-phase affinity, affinity precipitation (Tan, Kim, Yoo, \& Choe, 2007), and affinity electrophoresis (Anissimova, Baek, Varlamov, Mrabet, \& Vijayalakshmi, 2006).

\section{Conclusions}

The pore size and morphology of supermacroporous cryogels, prepared by the cryo-copolymerization of acrylamide monomers under freezing conditions, was influenced by variations in the monomer ratio (acrylamide and bis-acrylamide) and the presence/absence of the epoxy group (glycidyl allyl reagent donated by ether). The cryogels containing epoxy group presented better pore morphology, porosity and swelling capacity, as well as a firm structure. These cryogels also demonstrated a high permeability and low coefficient of liquid axial dispersion in a wide speed range.

With regard to the purification of lactoferrin, an interesting feature of this study is that the protein shows a high affinity for copper. The adsorption of proteins by IMAC is mainly determined by the presence of the histidine residues exposed on the protein surface. Factors such as accessibility to this residue (i.e., histidine, cysteine and tryptophan), microenvironment, cooperation between neighboring groups and local conformations play an important role in protein retention. In the case of copper ions, adsorption occurs via a single histidine residue. The primary structure of lactoferrin has two histidine residues, resulting in the high retention of lactoferrin in IDA-Cu${ }^{2+}$-cryogel. The IDA-Cu${ }^{2+}$ cryogel complex demonstrated promising results for the separation and purification of lactoferrin from cheese whey.

\section{References}

Anissimova, M. V., Baek, W. O., Varlamov, V. P., Mrabet, N. T., \& Vijayalakshmi, M. A (2006). Immobilized metal-ion affinity systems for recovery and structurefunction studies of proteins at molecular, supramolecular, and cellular levels. Journal of Molecular Recognition, 19, 287.

Arvidsson, P., Plieva, F. M., Lozinsky, V. I., Galaev, I. Y., \& Mattiasson, B. (2003). Direct chromatographic capture of enzyme from crude homogenate using immobilized metal affinity chromatography on a continuous supermacroporous adsorbent. Journal of Chromatography A, 986, 275-290.

Arvidsson, P., Plieva, F. M., Savina, I. N., Lozinsky, V. I., Fexby, S., Bülow, L., et al. (2002). Chromatography of microbial cells using continuous supermacroporous affinity and ion-exchange columns. Journal of Chromatography A, 977, 27-38.

Billakanti, J. M., \& Fee, C. J. (2009). Characterization of cryogel monoliths for extraction of minor proteins from milk by cation exchange. Biotechnology and Bioengineering, 103, 1155-1163.

Bradford, M. M. (1976). Rapid and sensitive method for quantitation of microgram quantities of protein utilizing principle of protein-dye binding. Analytical Biochemistry, 72, 248-254.

Bruce, L. J., \& Chase, H. A. (2001). Hydrodynamics and adsorption behaviour within an expanded bed adsorption column studied using in-bed sampling. Chemical Engineering Science, 56, 3149.

Carvalho, B. M. A., Da Silva, S. L., Silva, L. H. M., Minim, V. P. R., Da Silva, M. C. H., Carvalho, L. M., et al. (2014). Cryogel poly(acrylamide): Synthesis, structure and applications. Separation \& Purification Reviews, 43, 241-262.

Carvalho, B. M. A., Silva, L. H. M., Carvalho, L. M., Soares, A. M. Minim, L. A. \& Da Silva, S. L. (2013). Microcalorimetric study of the adsorption of lactoferrin insupermacroporous continuous cryogel with immobilized $\mathrm{Cu}^{2+}$ ions. Journal of Chromatography A, 1312, 1-9.

Cheeks, M. C., Kamal, N., Sorrell, A., Darling, D., Farzaneh, F., \& Slater, N. K. H. (2008). Immobilized metal affinity chromatography of histidine-tagged lentiviral vectors using monolithic adsorbents. Journal of Chromatography A, 13, 2705-2711.

Chen, C., Guo, Y., \& Guan \& Liu, H. (2007). Isolation of lactoferrin from acid whey by magnetic affinity separation. Separation and Purification Technology, 56, $168-174$.

Cimen, D., \& Denizli, A. (2012). Immobilized metal affinity monolithic cryogels for cytochrome c purification. Colloids and Surfaces B: Biointerfaces, 93, 29.

Dainiak, M. B., Kumara, A., Plieva, F. M., Galaev, I. Y., \& Mattiasson, B. (2004). Integrated isolation of antibody fragments from microbial cell culture fluids using supermacroporous cryogels. Journal of Chromatography A, 1045, 93-98.

Dainiak, M. B., Plieva, F. M., Yu, I., Galaev, R., \& Mattiasson, B. (2005). Separation of different microbial cells using IMAC supermacroporous monolithic columns. Biotechnology Progress, 21, 644-649.

Deraz, S., Plieva, F. M., Galaev, I. Y., Karlsson, E. N., \& Mattiasson, B. (2007). Capture of bacteriocins directly from non-clarified fermentation broth using 
macroporous monolithic cryogels with phenyl ligands. Enzyme and Microbial Technology, 40(4), 786-793.

Kumar, A., Bansa, I. V., Arvidsson, P., Roychoudhury, P. K., \& Mattiasson, B. (2006). Supermacroporous cryogel matrices for integrated protein isolation immobilized metal affinity chromatographic purification of urokinase from cell culture broth of a human kidney cell line. Journal of Chromatography A, 1103, $35-42$.

Kumar, A., Bansal, V., Nandakumar, K. S., Galaev, I. Y., Roychoudhury, P. K., Holmdahl, R., et al. (2006). Integrated bioprocess for the production and isolation of urokinase from animal cell culture using supermacroporous cryogel matrices. Biotechnology and Bioengineering, 93, 636-646.

Kumar, A., Plieva, F. M., Galaev, I. Y., \& Mattiasson, B. (2003). Affinity fractionation of lymphocytes using supermacroporous monolithic cryogel. Journal of Immunological Methods, 283, 185-194.

Lozinsky, V. I., Plieva, F. M., Galaev, I. Y., \& Mattiasson, B. (2001). The potential of polymeric cryogels in bioseparation. Bioseparation, 10(4-5), 163-188.

Noppe, W., Plieva, F. M., Galaev, I. Y., Vanhoorelbeke, K., Mattiasson, B., \& Deckmyn, H. (2006). Immobilized peptide displaying phages as affinity ligands purification of lactoferrin from defatted milk. Journal of Chromatography A, $1101,79-85$.

Noppe, W., Plieva, F. M., Vanhoorelbeke, K., Deckmyn, H., Tuncel, M., Tuncel, A., et al. (2007). Macroporous monolithic gels, cryogels, with immobilized phages from phage-display library as a new platform for fast development of affinity adsorbent capable of target capture from crude feeds. Journal of Biotechnology, 131(3), 293-299.

Persson, P. Baybak, O, Plieva, F. M. Galaev, I, Y, Mattiasson, B, Nilsson, B, et al. (2004). Characterization of a continuous supermacroporous monolithic matrices for chromatographic separation of large bioparticles. Biotechnology and Bioengineering, 88, 224.

Plieva, F. M., Andersson, J., Galaev, I. Y., \& Mattiasson, B. (2004). Characterization of polyacrylamide based monolithic columns. Journal of Separation Science, 27, $828-836$.

Plieva, F. M. Savina, I. N., Deraz, S., Andersson, J. Galaev, I. Y. \& Mattiasson, B. (2004). Characterization of supermacroporous monolithic polyacrylamide based matrices designed for chromatography of bioparticles. Journal of Chromatography B, 807, 129-137.
Porath, J., \& Olin, B. (1983). Immobilized metal ion affinity adsorption and immobilized metal ion affinity chromatography of Biomaterials. Serum protein affinities for geimmobilized iron and nickel ions. Biochemistry, 22, $1621-1630$.

Poster, M. T., Howard, K. S., Johnson, A. H., \& McMichael, K. L. (1980). Scanning eletron microscopy: A student's handbook (Vol. 1980. Williston, VT: Ladd Research Industries (pp. 182-240). Williston, VT: Ladd Research Industries.

Putter, J., \& Becker, R. (1983). In H. U. Bergmeyer (Ed.). Methods of enzymatic analysis (Vol. 3, pp. 283). Weinheim: Verlag Chemie.

Ribeiro, M. B., Vijayalakshmi, M., Todorova-Balvay, D., \& Bueno, S. M. A. (2008) Effect of IDA and TREN chelating agents and buffer systems on the purification of human IgG with immobilized nickel affinity membranes. Journal of Chromatography $B, 861,64$.

Tan, L. H., Kim, D. S., Yoo, I. K., \& Choe, W. S. (2007). Harnessing metal ion affinity for the purification of plasmid DNA. Chemical Engineering Science, 62, 5809.

Wakabayashi, H., Yamauchi, K., \& Takase, M. (2006). Lactoferrrin research, technology and applications. International Dairy Journal, 16, 1241-1251.

Wang, L., Shen, S., He, X., Yunb, J., Yao, K., \& Yao, S. J. (2008). Adsorption and elution behaviors of bovine serum albumin in metal-chelated affinity cryogel beds. Biochemical Engineering Journal, 42, 237-242.

Yao, K., Yun, J., Shen, S., Wang, L., He, X., \& Yu, X. (2006). Characterization of a novel continuous supermacroporous monolithic cryogel embedded with nanoparticles for protein chromatography. Journal of Chromatography A, 1109, 103-110.

Yun, J. X., Lin, D. Q., \& Yao, S. J. (2004). Characterization of a novel continuous supermacroporous monolithic cryogel embedded with nanoparticles for protein chromatography. Industrial and Engineering Chemistry Research, 43, 8066.

Yun, J. X., Yao, S. J., \& Lin, D. Q. (2005). Preparation of polyacrylamide-based supermacroporous monolithic cryogel beds under freezing-temperature variation conditions. Chemical Engineering Journal, 109, 123.

Zachariou, M., \& Hearn, M. T. W. (2000). Adsorption and selectivity characteristics of several human serum proteins with immobilized hard Lewis metal ion-chelate adsorbents. Journal of Chromatography A, 890, 95. 